\title{
An Analysis of EFL Students' Difficulties in Listening Comprehension at STKIP Muhammadiyah Bogor
}

\author{
Muhammad Khoerul Hadist*, Hidjanah, Dtakiyatuddaaimah, Lucky Dewanti \\ STKIP Muhammadiyah Bogor, Indonesia \\ *Coresponding Author: coiruel12@gmail.com
}

Article History:

Received 2021-12-29

Revised 2022-01-31

Accepted 2022-02-14

DOI:

10.31949/educatio.v8i1.1847

\begin{abstract}
The purpose of this study is to find out the difficulties or problems and the factor encounter by students in listening comprehension aimed to prepare teacher to belp Student difficulties and solve the problems during teaching. This research used qualitative descriptive method. The procedure data employ the questionnaire in collecting data. 61 EFL Students of STKIP Mubammadiyah Bogor as participants. Ther resultd revealed that there were some factors affected to EFL learner in listening comprehension such as listening material, listener attitude and background knowledge, speaker and physical setting, but the most difficulites faced students in this case were lengt speech its about 60\%, and unfamiliar words its about $80 \%$ in listening material variable. Meanwhile, for the listener attitude and background knowledge at the least there were two items the most difficulties faced such as catching linking word its about 54\% and catching proper word its about 44\%. The last and the most significant difficulties faced was the speaker and physical setting such as in unclear recorder resulting from poor CD or casset its is about $93 \%$, and poor of recording quality and poor of equipment both of them approximate $90 \%$.
\end{abstract}

Keywords:; Listening Comprehension; students difficulties

\section{INTRODUCTION}

There are some foreign languages are taught in Indonesian schools, one of them is English language. It's because English language is one of the subject metter that taught in Indonesian national curriculums which is include any level of educations there are elementary schools, junior high schools, senior high schools 
or even for college (Faridatuunnisa, 2020). So, an English language might one of the most popular foreign languages that taught in Indonesian country.

Listening skills is a component which is can't be sparated in learning a language, especialy in learning English language. Those things are prominent for every one who wants to acquiring other languages instead of speaking skills, reading skills, and writing skills. Listening skills can be gained by some training, drilling, or exercising throught out listening to a native speaker or video recorder, thus kinds of training can be provided by schools, college or any instantions of language learning center (Hadijah, 2018).

Hence, an English language as subject, and a listening skills as one skill, that have been taught by teachers in their schools, college and classroom. Therefore, it no wonder during learning and teaching emerged some difficulties or problems that students face in listening comprehension, especially English language as foreign language. So, the problems might be accoured and encountered by students in the class during learning. As the research conducted by Assaf (2015) in "The difficulties encountered by EFL learners in listening comprehension as perceived by ELC student at Arab American University - Jenin" which was engaged 189 participat consist of 95 males and 94 females and questionnaire and interview used as the instruments. The results was reveled that there are still some significant difiluties encountered in listening comprehension such as unable to recognize word, unfamiliar topic, noise around, poor of listening equipment.

In additons, in prior research conducted by N. Putri (2018) in an Indonesian university on "listening challenges faced by EFL students in academic listening class" which was fifty participants envolved as a sample and questionnaire and interview used to gaining data. The results showed that unfamiliar words, speed of speech, and lack of equipment still the most distinguited problems encounter by students. Those, two researches explained above tend, that external factore was dominated the causes.

In other hands, N. Sari (2019) in other approaches through in "Exploring EFL students" problems in listening comprehension" the observation, interview, and documentation employed to digging some data, and results merged, that the internal factore such as lack of confident in listening skill, and less of focusing in listening comprehension the most valuable problems that students faced.

Based on prior researchs explained above there are two major problems, that students EFL laerners faced in listening comprehension internal factor and external factor. Its corious to know the significant variable problems revealed in EFL students' listening comprehension. So the research should be focusing on an analysis of EFL students' difficulties in listening comprehension at STKIP Muhammadiyah Bogor.

The problems of listening comprehension sometimes happened in students. Zulfikar (2020) argued there some variable actually affected on students listening comprehension problems such as speaker variables, stimulus variable, background variables, and listener variables. The speaker variable is often caused by speaker speedy of speech, unclear pronounciation, lengt of speech. For the students who seldom exposure to the language sources, the fast utteren it would be trouble for them to catch what utterent said even for the messege that convied. In addition, stimulus as the variable that has considerable for shake of learning process, a good stimulant in listening learning process can give much more advantages. A background as the prominent in listening comprehension whether student had much more exposure to the model of topic or familiar topic, or familiar vocabularies it would help them to get better understanding during listening. The last is listener itselves, the ability of listenener affected to listening comprehensions probably it's caused by internal and external factors.

In the other hands, Saraswaty (2018) highlight some difficulites that students maight encounter in listening comprehension such as quality of recorder materials, cultural differences, accent, unfamiliar vocabularies, lengt and speed listening. Somehow, in listening learning process the material that teacher gave in classroom not always appropriate for the level of student knowledge or the recorder might have some demages during playing. In fact, languege that student learning and listen have different region even culture from their language so it might be found so many differences in linguistic area such as grammar, pronounciation, and syntax, and so on. Due to the differences of regional, area and location so the sound that produced by utterent when they speak it is no easy for the students to catch sometimes they miss some 
words, pharases or even sentences. Unfamiliar vocabulaliers might be found during listening process such a student problems. Lengt and speed speech it might become a problem to the student comprehension sometimes it is affected to the lack of students focusing.

Furthermore, according to Diora (2020) in his research there are three factors difficulties students faced in listening comprehension such as listening material, listener, and physical setting. The listening material such a stereotype in students EFL listening comprehension the various material that given to students it might not appropriate with their level of listening which is inhibited to students' listening comprehending that such as external factors. The sutudents or listeners itsselves might have various background of knowledge, and has any level in listening comprehension that such as internal factor or they haven't good attitude in listening subject. A laboratory and class as the place in delivering listening subject have a big effect to the succesfull of students' listening comprehension.

In addition Yilmaz (2015) assumed that there are four variables related to listening comprehension; the message, the speaker, listener and physical setting. Yilmaz has different view related to listening comprehension the message including the listening material as the variable that considerable in listening comprehension, but the two last variables have the same catagories with the researchers explained above. It can be concluded in general way of views that the major of listening comprehension difficulties divided into two major external factor and internal factor.

Somehow, regadling to Bakhtiarvan (2011) the variable that was affected to listening comprehension is EFL students' background knowledge, in his research "is listening comprehension influenced by the background knowledge of the learner?' the result revealed that it has significant effect to listening comprehension, so the problems might occoured in listening comprehension by their lack of knowledge or prior information. Furthermore, Taysi (2019) argued that students' attitude and anxiety affected throughtout listening comprehension thus variable has positive and negative result toward students' listening comprehension.

Based on the explanation above, there are some variable wich is related to students difficulties in listening comprehension they are listening material, listener, phsycal setting, attitude, and background knowledge. The writer assumed that there are three major factor as the variable; listening material, listener attitude and background knowledge, and phsycal setting. Therefore, the purpose of this study to figure out the problem ocoured in listening comprehension encountered by student STKIP Muhammadiyah collecge, due to provide best preparation and appropriate strategies in teaching listening comprehension.

\section{RESEARCH METHODS}

In finding the answer of the difficulties, factors caused to students in listening skill, so the researcher determined to employe qualitative descriptive for this research, according to Selinger and Shohamy (Diora \& Rosa, 2020) descriptive qualitative is the investigating research and it can be employed by some instrument . As well known that qualitative reseach instrument employ some instrument such as questionnaire, interview and observation for qualitative method most of them, but, actually in this case the researcher only use questionnaire for gaining and collecting the data the questionnaire used to collect some data. The questionnaire distributed to $61 \mathrm{EFL}$ students of STKIP Muhammadiyah Bogor using google form randomly. The questionnaire divided into three major variables; the listening material, listener attitude and background knowledge, speaker and physical setting. After gaining data was examining by simple percentages due to present in discussion and finding chapter (Hague, 2006; Punch, 2009).

\section{RESULT AND DISCUSSION}

1. Students difficulites related to listening material

As the table 1 showed in students difficulties related to listening material, there are some frequent answers in unfamiliars word, the most of students answer the unfamiliar word become the most difficulties that students faced during listening comprehension, its can be showen in table about unfamiliar word has $80.3 \%$ in percentages.

Open Access: https://ejournal.unma.ac.id/index.php/educatio 
Table 1. students difficulties related to listening material

\begin{tabular}{|c|c|c|c|c|}
\hline No & Questionnaire & $\mathrm{A}(\%)$ & $\mathrm{N}(\%)$ & DA $(\%)$ \\
\hline 1 & $\begin{array}{l}\text { Do you find listening material is not appropriate with your level of } \\
\text { English? }\end{array}$ & 27.9 & 55.7 & 16.4 \\
\hline 2 & $\begin{array}{l}\text { Do you find listening material is too hard for you in any } \\
\text { condition? }\end{array}$ & 10 & 58.3 & 31.7 \\
\hline 3 & Do you find difficult listen to sentences or long speech? & 60.7 & 24.6 & 14.8 \\
\hline 4 & $\begin{array}{l}\text { Do you find difficult for comprehending listening for whole if you } \\
\text { find unfamiliar vocabulary }\end{array}$ & 80.3 & 14.6 & 4.9 \\
\hline 5 & Do you find listening comprehension have a complex grammatical & 36.1 & 13.1 & 50.8 \\
\hline
\end{tabular}

The lengt of speech material or conversation become the second obstacle that students found during listening comprehension it is about $60.7 \%$ students answered, instead both of the most difficulties students encounter in listening comprehension unappropriate and a hard material as the lowest percentage and it is $10 \%$ for hard material and $27.9 \%$ for unapproriate material.

2. Students difficulties related to listener attitude and background knowledge

Table 2. Students difficulties related to listener attitude and background knowledge

\begin{tabular}{llccc}
\hline No & Questionnaire & $\mathrm{A}(\%)$ & $\mathrm{N}(\%)$ & $\mathrm{DA}(\%)$ \\
\hline 1 & $\begin{array}{l}\text { Do you don't like to listening comprehension subject } \\
2\end{array}$ & 13.1 & 45.9 & 41 \\
& $\begin{array}{l}\text { Do you seldom to listen to English recorder throughout music, } \\
\text { video ect? }\end{array}$ & 21.3 & 39.3 & 39.3 \\
3 & $\begin{array}{l}\text { Do you seldom or never to listen to English recorder before } \\
\text { enter the class? }\end{array}$ & 18 & 52.5 & 29.5 \\
4 & $\begin{array}{l}\text { Do you feel anxiety during listening comprehension classes? } \\
5\end{array}$ & 16.4 & 39.3 & 44.3 \\
6 & $\begin{array}{l}\text { Do you feel unhappy during listening comprehension classes? } \\
7\end{array}$ & 3.3 & 50 & 46.7 \\
& $\begin{array}{l}\text { Do you find difficult to catch sound appropriately? } \\
\text { utter a word linficult in catching sentence meaning when native }\end{array}$ & 54.3 & 42.6 & 13.1 \\
& & & & 11.5 \\
\hline
\end{tabular}

Some problems might encounter by student in listening comprehension are lack of attitude and lack of background knowledge or prior information. The result found that the most significan problems that student faced in listening comprehension was sthudents still find difficult to catching a meaning when native speaker spoke a linking word it might caused by their lack of knowledge or less prior information and the pecentages about $54.1 \%$ agreed this is the most one.

Comes after, catching a proper word that produced by speaker has the second problem faced by student in listening comprehension it also causes by their lack of background knowledge about how to differentiate pair word who have similar sound, and its about $44.3 \%$ students agreed. Meanwhile, students dislike to the listening comprehension subject and feeling anxiety in listening comprehension were the less, and it's $13 \%$ students dislike and $16.4 \%$ students were felt anxiety.

3. Students difficulties related to the speaker and physical setting

It's surpraisingly in this variable almost of students had more then fifty percent in each items of difficulties face in this variable and non of them had lower than fifty percent, that meant the speaker and physical setting the most variable caused to their listening comprehension. The three difficulties items it might be highlight as the most frequent such as unclear resulting from a poor quality of $\mathrm{CD}$ player approximately $93 \%$ students agreed, and students lost their consertation if the recording has a poor quality and unclear sound resulting from poor equipment both of them has same result its about $90 \%$. 
Table 3. Students difficulties related to the speaker and physical setting

\begin{tabular}{|c|c|c|c|c|}
\hline No & Questionnaire & $\mathrm{A}(\%)$ & $\mathrm{N}(\%)$ & $\mathrm{DA}(\%)$ \\
\hline 1 & Do you lose concentration if the recording has a poor quality? & 90.2 & 8.2 & 1.6 \\
\hline 2 & $\begin{array}{l}\text { Do you find difficult to understand when speaker has variety of } \\
\text { accent? }\end{array}$ & 61.7 & 31.7 & 6.7 \\
\hline 3 & $\begin{array}{l}\text { Do you find difficult to understand when the speaker spoke to } \\
\text { fast? }\end{array}$ & 86.9 & 9.8 & 3.3 \\
\hline 4 & Do you find difficult to concentration if noised around? & 85.2 & 11.5 & 3.3 \\
\hline 5 & $\begin{array}{l}\text { If unclear sounds resulting from poor equipment. Does } \\
\text { interference your listening comprehension? }\end{array}$ & 90.2 & 6.6 & 3.3 \\
\hline 6 & $\begin{array}{l}\text { When unclear resulting from a poor quality of CD player. Does } \\
\text { interference your listening comprehension? }\end{array}$ & 93.4 & 0 & 6.6 \\
\hline
\end{tabular}

The listener attitude and background knowledge in this research was the lowest variables that revealed among two others varialbels as in Saraswati (2018) research coundacted in teacher startegies to enhance student attitude toward listening problem throughtout students. Meanwhile, the listening material as the second problems often occoured in this research and its in line with Erzad (2020) research, there were some problems related to listening in Students IAIN Kudus such as speedy of speech and lengt of listening in coherence with listening material. In addition, the speaker and the setting was the most variables problems occoured in the research and its mutually supported with Diora (2020) in his previous research related to students FBS UNP listening problems were reveled speaker and physical setting as the most variable encountered by students.

\section{CONCLUSION}

Since listening comprehension is the prominat part instead speaking, reading and writing skill in acquiring another language, and its is had been taught in most of indonesia university. The result finding that the listening material, student attitude, and setting were influnced students listening comprehension and caused the problems in listening comprehension. Meanwhile, this research as the earlier diagnotic to the students problems or diffiulties and factor especially in listening comprehension to help more for the teacher and the students EFL to minimize the problems or difficulties that might encounterd during teaching and learning. Hopfuly, this early clinical dioagnostic in students listening problems can hlep teacher and student to prepare their best strategies and preparation in learning and teaching regadling to English listening comprehension.

\section{REFERENCES}

Assaf, A. H. (2015). The Difficulties Encountered by EFL Learners in Listening Comprehension as Perceived by ELC Students at the Arab American University-Jenin. In Difficulties in Listening Comprehension (Issue listening comprehension).

Bakhtiarvand, M., \& Adinevand, S. (2011). Is listening comprehension influenced by the cultural knowledge of the learners? A case study of Iranian EFL pre-intermediate learners. RELC Journal, 42(2), 111-124. https://doi.org/10.1177/0033688211401257

Diora, L., \& Rosa, R. N. (2020). Journal of English Language Teaching An Analysis Of Students' Difficulties In Listening Comprehension: A Descriptive Study At English Language And Literature Department FBS UNP. Journal of English Language, 9(1), 87-98. http:// ejournal.unp.ac.id/index.php/jelt

Erzad, A. M. (2020). Exploring English Listening Problems Among Efl Students At Iain Kudus. Edulingua: Jurnal Linguistiks Terapan dan Pendidikan Bahasa Inggris, 7(1). 
Faridatuunnisa, I. (2020). Kebijakan Dan Pelaksanaan Pembelajaran Bahasa Inggris Untuk Sd Di Indonesia. In Seminar Nasional Pendidikan (pp. 191-199).

Gilakjani, A. P., \& Ahmadi, M. R. (2011). A Study of Factors Affecting EFL Learners' English Listening Comprehension and the Strategies for Improvement. Journal of Language Teaching and Research, 2(5), $977-$ 988. https://doi.org/10.4304/jltr.2.5.977-988

Hadijah, S., \& Shalawati, S. (2018). Listening Comprehension Strategies Applied by English Language Learners. ELT-Lectura, 5(1), 38-47.

Hague, P. (2006). An Introduction to Questionnaire Design. A Practical Guide to Market Research, 129-149. https://www.b2binternational.com/files/08-market-research-ch8.pdf

Harding, L., Alderson, J. C., \& Brunfaut, T. (2015). Diagnostic assessment of reading and listening in a second or foreign language: Elaborating on diagnostic principles. Language Testing, 32(3), 317-336. https://doi.org/10.1177/0265532214564505

Koryati, Evawati, N. M., \& Zulkifli. (2017). The Implementation of Diagnostic Approach Strategy to Improve The Students' Listening Skill. Holistics Journal, 9(18), 42-47.

Punch, K. F. (2009). The Analysis of Qualitative Data. In Introduction to Research Methods in Education (p. 398). http://books.google.com/books?hl=en\&lr=\&id=lBvMqiaN5EgC\&pgis=1

Putri, N. (2018). Listening Challenges Faced By Efl Students in Learning. Universitas Kristen Satya Wacana.

Rara Saraswaty, D. (2018). Learners' Difficulties \& Strategies In Listening Comprehension. In English Community Journal (Vol. 2, Issue 1). http://jurnal.um-palembang.ac.id/englishcommunity/index

Raza, M. A. L. I. (2020). Teaching Listening to EFL Students Teaching Listening to EFL Students. June 2016. https://doi.org/10.6084/m9.figshare.11640267

Sari, N., \& Fithriyana, R. (2019). Exploring EFL Students' Problems in Listening Comprehension. JEES (Journal of English Educators Society), 4(1), 47-52. https://doi.org/10.21070/jees.v4i1.1722

Tayşi, E. K. (2019). The effect of listening attitude and listening anxiety on listening comprehension: A regression model. Universal Journal of Educational Research, 7(2), 356-364. https://doi.org/10.13189/ujer.2019.070207

Yilmaz, H., \& Yavuz, F. (2015). The Problems Young Learners Encounter During Listening Skills. Procedia Social and Behavioral Sciences, 197, 2046-2050. https://doi.org/10.1016/j.sbspro.2015.07.570

Zulfikar, Z., Aulia, C. T., \& Akmal, S. (2020). Exploring Efl Students' Problems In Listening To English News Broadcasts. Language Literacy: Journal of Linguistics, Literature, and Language Teaching, 4(2), 340-352. https://doi.org/10.30743/1l.v4i2.2940 